\title{
Rearing diet may determine fish restocking success: a case study of hatchery-reared juvenile meagre, Argyrosomus regius
}

\author{
María del Mar Gil 1,2, Miquel Palmer ${ }^{2}$, María Dolores Hernández ${ }^{3}$, Amalia Grau ${ }^{1}$, \\ Juana Durán ${ }^{1}$, Benjamín García García ${ }^{3}$, Miguel Jover ${ }^{4}$, Elena Pastor ${ }^{1}$ \\ ${ }^{1}$ Laboratori d'Investigacions Marines i Aqüicultura, LIMIA (Balearic Government). C/ Eng. Gabriel Roca 69, \\ 07157 Port d'Andratx, Balearic Islands, Spain.E-mail: mmgil@ dgpesca.caib.es \\ ${ }_{2}^{2}$ IMEDEA (UIB-CSIC), Instituto Mediterráneo de Estudios Avanzados, Department of Ecology and Marine Resources, \\ Fish Ecology Group. C/ Miquel Marquès 21, 07190 Esporles, Balearic Islands, Spain. \\ ${ }^{3}$ IMIDA Acuicultura. Consejería de Agricultura y Agua de la Región de Murcia. P.O. 65, 30740 San Pedro del Pinatar, \\ Murcia, Spain. \\ ${ }^{4}$ Grupo de Acuicultura y Biodiversidad. Universitat Politècnica de Valencia. Camino de Vera 14, 46022 Valencia, Spain.
}

\begin{abstract}
The resilience of released hatchery-reared specimens increases with age and size, but production costs are also greater for these individuals. Therefore, for a given budget, the consequences of increasing age and size impose a trade-off between producing a large number of vulnerable (small) fish or a small number of resilient (large) fish. Once the optimal size for releasing fish has been defined, the choice of rearing protocol will determine the number and quality of the fish that can be released. In this study, different rearing protocols were compared using meagre juveniles (Argyrosomus regius), which are presently the target of a restocking programme conducted in the Balearic Islands (western Mediterranean). Seven different diets were compared during the grow-out phase to identify the diets that produced good-quality juveniles of a given size at the lowest cost. Most of the diets produced juveniles of suitable biological quality in terms of growth, fish condition (relationships between length and total weight, liver weight and mesenteric fat weight) and tissue biochemical composition. A semi-moist diet (Diet G) provided the best growth rate, closely followed by commercial meagre pellets (Diet A). In contrast, the cost of growing fish with Diet A was lower for any possible size at release. This study demonstrates the need to consider both growth rate and production cost to select the rearing protocol that maximizes the number of juveniles that can be produced for a given budget and desired release size. These considerations will ultimately increase the chance of success of restocking programmes.
\end{abstract}

Keywords: Argyrosomus regius; restocking programme; production cost; fish quality; diet.

La dieta usada en la cría puede determinar el éxito en la repoblación de peces: el caso de juveniles de corvina Argyrosomus regius criados en cautividad

Resumen: La resiliencia de los ejemplares criados en cautividad y liberados se incrementa con la edad y el tamaño, pero los costes de producción también aumentan. Por lo tanto, para un presupuesto dado, estas consecuencias del incremento de la edad y el tamaño imponen un compromiso entre la producción de un gran número de peces vulnerables (pequeños) o un pequeño número de peces resistentes (grandes y de más edad). Una vez que el tamaño óptimo para la liberación de peces se ha definido, la elección del protocolo de cría determinará el número y la calidad de los peces que se pueden liberar con un presupuesto dado. En este estudio, se comparó la aplicación de diferentes protocolos de cría a juveniles de corvina (Argyrosomus regius), que es la especie objetivo de un programa de repoblación llevado a cabo en las Islas Baleares (Mediterráneo occidental). Se compararon siete dietas diferentes durante la fase de engorde para identificar cuáles de ellas podrían producir juveniles de buena calidad, de un tamaño dado y al menor coste. La mayoría de las dietas produjeron juveniles de calidad biológica adecuada en términos de crecimiento, condición del pez (estimada a partir de la relación de la longitud con el peso total, el peso del hígado y el peso de la grasa mesentérica) y composición bioquímica del tejido. Una dieta semi-húmeda (Dieta $\mathrm{G})$ proporcionó la mejor tasa de crecimiento, seguida de cerca por un pienso comercial de corvina (Dieta A). Por el contrario, el coste del cultivo de peces con la Dieta A fue menor para cualquier posible tamaño de suelta. Este estudio demuestra la necesidad de considerar tanto la tasa de crecimiento como los costes de producción, con el fin de seleccionar el protocolo de cría que maximiza el número de juveniles que pueden ser producidos para un determinado presupuesto y tamaño de liberación deseado. Estas consideraciones aumentarán, en última instancia, las posibilidades de éxito de los programas de repoblación.

Palabras clave: Argyrosomus regius; programa de repoblación; coste de producción; calidad de los peces; dieta.

Citation/Como citar este artículo: Gil M.M., Palmer M., Hernández M.D., Grau A., Durán J., García García B., Jover M., Pastor E. 2015. Rearing diet may determine fish restocking success: a case study of hatchery-reared juvenile meagre, Argyrosomus regius. Sci. Mar. 79(4): 431-441. doi: http://dx.doi.org/10.3989/scimar.04140.05A 
Editor: E. Mañanos.

Received: August 16, 2014. Accepted: July 13, 2015. Published: October 6, 2015.

Copyright: () 2015 CSIC. This is an open-access article distributed under the Creative Commons Attribution-Non Commercial Lisence (by-nc) Spain 3.0.

\section{INTRODUCTION}

The use of hatchery-reared fishes to enhance wild stocks (hereafter "restocking") has attracted increasing interest (Cowx 1994, Munro and Bell 1997, Bartley and Bell 2008) due to dramatic decreases in yield and even the collapse of some fisheries (Wilby et al. 2009). A steadily growing number of species and countries have been involved in restocking programmes over recent years (Born et al. 2004). The annual budget invested in rearing hatchery fish and releasing them to the wild is not known precisely, but it is in the range of billions of dollars (Brown and Day 2002). Restocking has been criticized because it may be neither effective nor economically viable (Bell et al. 2006). Therefore, an appropriate restocking-based management strategy should employ a number of pilot studies to assess the actual effects of restocking on stock enhancement and to develop strategies that maximize the profit of stocking while minimizing its environmental impact and economic cost (Blankenship and Leber 1995).

The success of restocking programmes depends on how well the hatchery-reared fishes can adapt to natural habitat conditions and survive once released (Ireland et al. 2002). However, post-release survival may be low due to the inexperience of released animals in wild conditions (Iglesias et al. 2003, Sparrevohn and Støttrup 2007). Thus, releasing a very large number of juveniles is often needed to ensure the success of restocking programmes (Bartley and Bell 2008), which implies high cost. Moreover, post-release survival is mediated by the size of individuals at the time of release (Tsukamoto et al. 1989, Svåsand and Kristiansen 1990, Leber et al. 2005), and releasing undersized fish seems to be largely ineffective (Kristiansen et al. 1997). However, the size at which fishes are released is also strongly governed by economic constraints. Most of the budget of restocking projects is invested in production costs (Ungson et al. 1993). These costs include the maturation, hatchery, nursery and grow-out phases (Leung et al. 1993, Kam et al. 2002). Therefore, the longer the fish remain in captivity, the greater the cost to feed and house them (Tominaga and Watanabe 1998, Brown and Day 2002), and fewer fish may be released within a fixed budget. Consequently, the optimum release size would result from a trade-off between size-dependent survival rates, growth rates and production costs (Leber 1995).

In addition to fish size, maximizing survival of released fish depends on biological quality (Leber 1995, Tominaga and Watanabe 1998, Tsukamoto et al. 1999, Le Vay et al. 2007). Quality not only refers to the release of disease- and deformity-free fish but also implies particular physiological and nutritional characteristics. Physiological welfare can be evaluated by body condition, and nutritional quality is directly assessed by tissue composition (Pepper et al. 1992, Le Vay et al. 2007). Biological quality has been directly related to the quality of the diet used to feed the larvae or juveniles (Le Vay et al. 2007). Therefore, an optimal diet allows the production of quality fish and also provides good growth rates.

Here we examine the meagre, Argyrosomus regius (Asso, 1801). This fish, belonging to the family Sciaenidae, is distributed along the eastern Atlantic coast (from Norway to Congo) and throughout the entire Mediterranean (Chao 1986). In Mediterranean waters, the abundance of meagre has decreased alarmingly (Quéro and Vayne 1987, Sadovy and Cheung 2003). Indeed, this species is considered extinct in the Balearic Islands, where it was frequently captured by the artisanal fleet only a few decades ago (Mayol et al. 2000). Consequently, a consortium composed of policy makers from the local government (Balearic Government), researchers from LIMIA (Laboratori d'Investigacions Marines i Aqüicultura, Balearic Government) and IMEDEA (Instituto Mediterráneo de Estudios Avanzados, CSIC-UIB), and local fishermen (associations of artisanal fishermen and recreational fishing clubs) have launched a restocking programme.

As meagre is considered an emerging species in European aquaculture (Monfort 2010), numerous studies related to rearing conditions and growth have been conducted in recent years with a view to improving production (Piccolo et al. 2008, Roo et al. 2010, Estévez et al. 2011, Vargas-Chacoff et al. 2014, VelazcoVargas et al. 2014). In contrast, the main objective of this study was to determine the optimal rearing protocol for obtaining juveniles suitable for restocking, considering both biological and economic aspects. To this end, growth, physiological quality (body condition indices), nutritional quality (tissue composition) and cost of seven different diets were compared to identify the optimal diet for producing juveniles of a desired release size at the lowest cost, thus facilitating the release of the greatest number of specimens.

\section{MATERIALS AND METHODS}

Meagre were spawned in May at LIMIA facilities using protocols developed by LIMIA (Pastor and Grau 2013). Eggs were obtained by hormonal induction of meagre breeders captured in the Bay of Cádiz. During the hatchery phase, the larvae were reared under controlled conditions and fed a diet composed of rotifers (day 2-15) and Artemia sp. (day 8-30). The fish fry were fed commercial feed (Skretting ${ }^{\circledR}$, Burgos, Spain; day >30) and were maintained in tanks and later in small sea cages during the nursery and pre-grow-out phases. 
Table 1. - Tested diets.

\begin{tabular}{lll}
\hline Experiment & $\begin{array}{c}\text { Diet } \\
\text { tested }\end{array}$ & \multicolumn{1}{c}{ Origin } \\
\hline 1 & A & Meagre commercial pellet 1 \\
& B & Seabass commercial pellet \\
2 & C & 45P/17F experimental composition \\
& D & 47P/20F experimental composition \\
3 & E & 49P/22F experimental composition \\
& A & Meagre commercial pellet 1 \\
& F & Meagre commercial pellet 2 \\
& G & Semi-moist diet (OMP, Oregon Moist Pellet) \\
\hline
\end{tabular}

\section{Diet experiments}

Juvenile meagre obtained from the pre-grow-out phase were transferred to experimental sea cages ( 8 $\mathrm{m}^{3}$ ) and fed seven different diets (Table 1). Due to logistical constraints (i.e. only eight experimental cages were available at the LIMIA facilities), it was not possible to compare the seven diets within a single year, and three experiments were performed with juveniles born in each of 2006, 2007 and 2008. Some cages received the same treatment (Diet A) in two different years (Table 1) to estimate the between-year variability. Assuming that between-year variability in growth was similar for all diets, meagre length-at-age could be compared between diets even with these logistical constraints (see details of the statistical model below).

The macronutrient composition of the tested diets is shown in Table 2. Gross energy was calculated using energy coefficients (Miglavs and Jobling 1989).

The food ration (FR, i.e. amount of food provided daily per cage) was continuously adjusted as a function of water temperature, fish size, total biomass and pellet size, following the instructions given by Skretting ${ }^{\circledR}$. Every month, approximately 20-30 fish per cage were measured (total length, L) and weighed (W) to monitor growth and to adjust the food ration for the increasing biomass.

\section{Experiment 1}

During the first year, we compared meagre and seabass (Dicentrarchus labrax) commercial pellets, Diets A and B, respectively (Table 1). This experiment was performed over a period of 11 months (November 2006-October 2007) with juveniles born in 2006. A total of 635 fish (mean $\mathrm{W} \pm$ sd: $154.7 \pm 48.5 \mathrm{~g}$; mean $\mathrm{L} \pm \mathrm{sd}: 23.7 \pm 2.6 \mathrm{~cm}$ ) were distributed in 4 sea cages $(2$ replicate cages per treatment).

\section{Experiment 2}

Juvenile meagre born in 2007 were subjected to three experimental diets for eight months (December 2007-August 2008). These experimental diets were formulated using fish meal, fish oil, and wheat and soya oil. Feed was produced by extrusion with a Clextral BC-45 (France). The diets had different protein/ fat ratios $(45 \mathrm{P} / 17 \mathrm{~F}, 47 \mathrm{P} / 20 \mathrm{~F}$ and $49 \mathrm{P} / 22 \mathrm{~F})$. Approximately 250 fish per cage (mean $\mathrm{W} \pm \mathrm{sd}: 121.3 \pm 15.5 \mathrm{~g}$; mean $\mathrm{L} \pm \mathrm{sd}: 21.5 \pm 0.9 \mathrm{~cm}$ ) were transferred to eight experimental cages. Three of the cages were supplied with experimental Diet C, two with Diet D and three with Diet E (see Table 1 for details on the diets).

\section{Experiment 3}

The third experiment was performed with fish born in 2008 and lasted for 8 months (February 2009-October 2009). Approximately 86-87 juveniles per cage (mean W \pm sd: $95.8 \pm 20.9 \mathrm{~g}$; mean L \pm sd: $20.4 \pm 1.4 \mathrm{~cm}$ ) were stocked in 8 experimental cages. In this experiment the fish density was lower than in the other experiments, due to the reduced availability of meagre that year. However, in all experiments fish density was low $\left(<4 \mathrm{~kg} \mathrm{~m}^{-3}\right)$ compared with the $50 \mathrm{~kg} \mathrm{~m}^{-3}$ maximum (Lazo et al. 2010) and was not expected to affect fish growth. Three cages were fed with experimental Diet A (the same meagre commercial pellet used in Experiment 1) and three with Diet F (another type of meagre commercial pellet). Two cages were fed with Diet G, a semi-moist diet (OMP, Oregon Moist Pellet) prepared at the LIMIA facilities by mixing raw fish, fish flour and fish oil in a proportion of 10:10:1, respectively. The rations of Diet $\mathrm{G}$ were adjusted for moisture content such that each treatment received the same ration on a dry weight basis (Millamena 2002).

\section{Growth}

The length-at-age dataset obtained from the diet experiments was fitted to the growth model proposed by Somers (1988), a version of the conventional von Bertalanffy growth model that incorporates seasonal growth oscillations (García-Berthou et al. 2012). These seasonal oscillations are mainly dependent on temperature but also on photoperiod (Pauly 1990).

The model was also modified to ensure that growth was initiated at the beginning of the grow-out phase because age and length were known at that time. The model was as follows (note that subindices referencing

Table 2. - Proximate composition of the tested diets expressed as a percentage of dry matter.

\begin{tabular}{|c|c|c|c|c|c|c|c|}
\hline Diet & A & $\mathrm{B}$ & $\mathrm{C}$ & $\mathrm{D}$ & $\mathrm{E}$ & $\mathrm{F}$ & G \\
\hline Dry matter & 94.34 & 93.16 & 91.52 & 90.79 & 89.92 & 92.73 & 64.87 \\
\hline Crude protein & 48.77 & 49.20 & 46.12 & 48.63 & 49.38 & 49.17 & 53.39 \\
\hline Crude fat & 18.70 & 16.62 & 14.14 & 17.12 & 19.51 & 16.47 & 20.43 \\
\hline Ash & 7.77 & 6.80 & 8.98 & 9.43 & 9.76 & 10.44 & 9.36 \\
\hline Fibre & 1.57 & 1.84 & 2.10 & 1.00 & 0.89 & 2.10 & 1.89 \\
\hline NFE (Nitrogen free extract) & 24.13 & 27.38 & 28.66 & 23.82 & 20.45 & 21.82 & 14.93 \\
\hline Gross energy (MJ kg-1 feed) & 22.81 & 22.65 & 21.17 & 22.11 & 22.66 & 21.66 & 23.04 \\
\hline Protein/energy ratio (g protein/MJ) & 21.37 & 21.72 & 21.78 & 21.98 & 21.79 & 22.70 & 23.17 \\
\hline
\end{tabular}


fish have been omitted):

$$
\begin{aligned}
\mathrm{L}_{\mathrm{t}}=\mathrm{L}_{0 \text { year }}+\left(\mathrm{L}_{\infty}-\mathrm{L}_{0 \text { year }}\right)\left(1-\exp \left(-\mathrm{K}_{\text {cage }}\left(\mathrm{t}-\mathrm{t}_{0 \text { year }}\right)-\right.\right. & \\
& \left.\left.-\mathrm{S}_{\mathrm{t}, \text { year }}+\mathrm{S}_{\mathrm{t} 0 \text {, year }}\right)\right)+\varepsilon_{\mathrm{t}},
\end{aligned}
$$

where

$$
\begin{gathered}
\mathrm{S}_{\mathrm{t}, \text { year }}=\left(\mathrm{CK}_{\text {cage }} / 2 \pi\right) \sin \left(2 \pi\left(\mathrm{t}-\mathrm{t}_{\mathrm{S} \text { year }}\right)\right) \\
\mathrm{S}_{\mathrm{t} 0, \text { year }}=\left(\mathrm{CK}_{\text {cage }} / 2 \pi\right) \sin \left(2 \pi\left(\mathrm{t}_{0 \text { year }}-\mathrm{t}_{\mathrm{S} \text { year }}\right)\right) \\
\mathrm{K}_{\text {cage }} \sim \operatorname{Normal}\left(\mathrm{K}_{\text {year }}+\mathrm{K}_{\text {diet }}, \mathrm{sd}_{\text {cage }}\right) \\
\mathrm{K}_{\text {year }} \sim \operatorname{Normal}\left(0, \mathrm{sd}_{\text {year }}\right) \\
\varepsilon_{\mathrm{t}} \sim \operatorname{Normal}\left(0, \mathrm{sd}_{\varepsilon}\right)
\end{gathered}
$$

and where $\mathrm{L}_{0}$ is the mean fish length at the beginning of the grow-out phase $\left(\mathrm{L}_{0}\right.$ was measured and varied between years); $L_{\infty}$ is the length at asymptotic infinite age; and $\mathrm{K}$ is the rate of approach to the asymptotic length (Schnute and Fournier 1980) (hereafter, growth rate). Note that the growth rate estimated for a specific cage $\left(\mathrm{K}_{\text {cage }}\right)$ was considered a random realization from a normal distribution. The mean of this distribution results from combining a fixed component $\left(\mathrm{K}_{\text {diet }}\right)$ and a random component $\left(\mathrm{K}_{\text {year }}\right)$ that accounts for between-year variability. Therefore, data from different cages and years can be combined with a single hierarchical mixed model. In our study, $\mathrm{t}_{0}$ is the age at the beginning of the grow-out phase rather than the typical theoretical age at which the length would be zero; $t_{0}$ was known and varied between years. $\mathrm{C}$ modulates the amplitude of the seasonal growth oscillations; $t_{S}$ is the time between $t_{0}$ and the inflection point of the first sinusoidal growth oscillation; and $\mathrm{sd}_{\varepsilon}$, $\mathrm{sd}_{\text {year }}$ and $\mathrm{sd}_{\text {cage }}$ are the standard deviations of the corresponding levels of the hierarchical mixed model.

In our study, $\mathrm{L}_{0}$ was known (depending on the year, approximately $21 \mathrm{~cm}$ or $100 \mathrm{~g}$ ). $\mathrm{L}_{\infty}$ was assumed to be $171.9 \mathrm{~cm}$, as estimated by González-Quirós et al. (2011); although the value of this parameter did not affect the estimates of size-at-age, as previously determined by sensitivity analysis. Sensitivity analyses compared the estimates of size-at-age at $\mathrm{L}_{\infty}=150$, 171.9 and $200 \mathrm{~cm}$. Depending on the year, $\mathrm{t}_{0}$ oscillated between the ages of 6 and 9 months. The remaining parameters $\left(\mathrm{C}, \mathrm{K}_{\text {diet }}\right.$ and $\left.\mathrm{t}_{\mathrm{S}}\right)$ were estimated. Note that the seasonal oscillation included in the growth model allowed for comparison of the experiments with different starting dates.

The model parameters were estimated using a Bayesian approach. A non-informative normal distribution (zero mean and tolerance $=10^{-6}$ ) for $\mathrm{K}_{\text {diet }}$ and a uniform distribution for $\mathrm{C}$ and $\mathrm{t}_{\mathrm{S}}$ were assumed as priors. $\mathrm{C}$ was constrained to be within the interval $(0,1)$ (García-Berthou et al. 2012), and $\mathrm{t}_{\mathrm{S}}$ was constrained to be between 1 and 365 days. Three chains were run using randomly selected initial values for each parameter within a reasonable interval, and conventional convergence criteria were checked. The number of iterations was selected for each run to obtain at least 1000 valid values after convergence and thinning. The models were implemented in R (at http://www.r-project.org/) using the library R2jags (http://cran.r-project.org/web/ packages/R2jags/R2jags.pdf) with the samplers implemented in JAGS (http://mcmc-jags.sourceforge.net/).

\section{Fish quality}

At the beginning, middle and end of each experimental period, 10 animals per cage were sacrificed following the officially authorized animal care protocol, and data on fish length and total weight, as well as weights of liver and mesenteric fat, were recorded. These data were used to evaluate the biological condition of the fish based on the relationships between the length and total weight, liver weight and mesenteric fat weight. The biological condition represents the fatness of individuals at a given length (Marshall et al. 2004); therefore, higher values indicate better quality, or vigour, and greater energy reserves, which accumulate primarily in the liver and mesenteric fat.

The sample size for estimating the total weightlength relationship included the monthly samples obtained to adjust the rations (see above). The sample sizes are detailed below.

The weight-length relationship was defined by the equation $\mathrm{W}=\alpha \mathrm{L}^{\beta}$ and was converted into a linear regression by logarithmic transformation. The mesenteric fat weight was zero in some fish; therefore, logarithmic transformation was possible only by adding a factor of 0.01 to all observations. In all cases, the regression line was forced to pass through the known intercept $\left(\mathrm{W}_{0}\right.$ and $\mathrm{L}_{0}$; note that fish measured at $\mathrm{t}_{0}$ were only used for estimating mean $\mathrm{W}_{0}$ and $\mathrm{L}_{0}$ but were not included in other analyses). Therefore, the only unknown parameter of the model was $\beta$ (the slope):

$$
\begin{gathered}
\log \left(\mathrm{W}_{\mathrm{i}}-\mathrm{W}_{0 \text { year }}\right)=\beta_{\text {cage }}\left(\log \left(\mathrm{L}_{\mathrm{i}}-\mathrm{L}_{0 \text { year }}\right)\right)+\varepsilon_{\mathrm{i}} \\
\beta_{\text {cage }} \sim \operatorname{Normal}\left(\beta_{\text {year }}+\beta_{\text {diet }}, \mathrm{sd}_{\text {cage }}\right) \\
\beta_{\text {year }} \sim \text { Normal }\left(0, \mathrm{sd}_{\text {year }}\right) \\
\varepsilon_{\mathrm{i}} \sim \operatorname{Normal}\left(0, \mathrm{sd}_{\mathrm{W}}\right)
\end{gathered}
$$

$\beta_{\text {diet }}$ was determined using a Bayesian approach and the same random-effects hierarchical structure used for analysing growth outlined in the previous section. Normal non-informative priors were assumed. Prior to these analyses, the raw data were submitted to an outlier removal procedure using the function influence. measures of the R package. To simplify the interpretation of the results and to assess the differences between diets, weights (total, liver and mesenteric fat) were estimated for a desired size at release of $30 \mathrm{~cm}$. This reference point was selected as an example of a reasonable release size because no or very few fish smaller than $30 \mathrm{~cm}$ were recaptured in the course of the meagre restocking programme (Gil et al. 2015).

The proximate composition of the diets and of the entire fish were determined following the procedures of the AOAC (1997). After the measurements had been made, all fish samples were frozen at $-20^{\circ} \mathrm{C}$ until fur- 
ther analysis. After homogenization of the samples, the crude protein (Kjeldahl method, with a 6.25 nitrogen-toprotein conversion factor), crude fat (ethyl-ether extraction using a SOXTEC System HT6 extractor), moisture (drying at $105 \pm 1^{\circ} \mathrm{C}$ to constant weight), and total ash (incineration at $450 \pm 2^{\circ} \mathrm{C}$ to constant weight) contents were determined. The diets were also tested for crude fibre (Weende method). All analyses were performed in triplicate. The means and standard deviations of proximate composition were computed for each diet at the end of the three experiments. Statistically significant differences between means were evaluated with a oneway analysis of variance with $\alpha=0.05$. Post hoc pairwise comparisons were conducted with a Tukey test. These statistical analyses were performed with the $\mathrm{R}$ package.

\section{Production costs}

To determine the length-dependent economic costs of the meagre grow-out phase for the different diets, the costs related to feeding and personnel were analysed. Costs $(\mathrm{CO})$ were calculated per fish and expressed in euros $(€)$ using the following expression:

$$
\mathrm{CO}_{\text {diet }}=\mathrm{FCO}_{\text {diet }}+\mathrm{PCO}_{\text {diet }} \text {. }
$$

The feeding cost (FCO) depends on the accumulated daily food ration (i.e. the amount of feed supplied per day, $\mathrm{FR}_{\text {day }}, \mathrm{kg}$, which depends on the temperature, fish size and pellet size $)$ and the price $\left(\mathrm{P}, € \mathrm{~kg}^{-1}\right)$ of each tested diet. Additionally, because we assumed that the fish were fed only $74 \%$ of all the days of the experiments, this cost was multiplied by a factor of 0.74 .

$$
\mathrm{FCO}_{\mathrm{t}}=\sum_{\text {day }=1}^{\mathrm{t}} \mathrm{FR}_{\text {day,diet }} \mathrm{P}_{\text {diet }} 0.74
$$

The prices were very similar (approximately $1 €$ $\mathrm{kg}^{-1}$ ) for all the feeds with the exception of Diet $\mathrm{G}$. The raw materials for Diet $G$, especially fresh fish, were more expensive. Accordingly, the cost of the resulting diet was approximately twice that of the other diets. Moreover, due to its higher moisture content, the food ration was greater.

The daily food ration $\left(\mathrm{FR}_{\text {day }}\right)$ depends on the fish weight $(\mathrm{W})$, which was calculated from the length $(\mathrm{L})$ with the model

$$
\mathrm{W}=\alpha \mathrm{L}^{\beta},
$$

where $\alpha$ and $\beta$ were determined empirically by pooling several data sets collected at LIMIA.

The personnel cost per fish (PCO) depends on the salary per day $(\mathrm{S})$, the number of fish finally produced in a given year (estimated to be approximately 3000 juveniles per year for the LIMIA facilities), the days (D) required on each diet to achieve the desired length and the factor 0.74 because the fish were not fed every day.

$$
\mathrm{PCO}=\mathrm{S} \mathrm{D}(0.74 / 3000)
$$

The costs estimated for each diet allowed us to evaluate the most suitable diet for growing the maximum number of juvenile meagre to any desired release size. For example, for comparative purposes, the number of $30-\mathrm{cm}$ fish that can be produced with a given budget of $€ 1000$ could simply be estimated by the ratio of budget/cost-per-fish. However, some fish will die before release, thus implying an additional cost that is not accounted for by analysing only released fish. Therefore, the number of fish finally released was readjusted after taking into account fish losses produced during the grow-out phase (i.e. within the cages). The daily mortality rate $\left(0.012 \%\right.$ day $^{-1}$; unpublished data) was assumed on the basis of empirical data from LIMIA, after pooling data from different meagre experiments.

\section{RESULTS}

\section{Effect of diet on growth}

A total of 5174 length-at-age observations on 3331 fish fed one of seven different diets were successfully fitted to the proposed growth model. Due to the model complexity, preliminary fit of the data to the Somers' growth model at the cage level (i.e. independent analysis for each cage) was verified through visual exploration (Fig. 1). Next, all the data were combined in a single analysis using the hierarchical mixed model described above to compare between-diet performance. The fitted growth curves for each diet are shown in Figure 2. The best growth was obtained with diet G, although diet A also showed good growth performance. The growth rates of the fish fed the experimental diets (C, D and E) were clearly slower in comparison with the fish fed the other diets (Table 3 ).

\section{Quality of juveniles}

The slopes of the weight-length relationships (logtransformed), i.e. total weight, liver weight and mesenteric fat weight, for the different diets were estimated using the model detailed above based on 5360 fish for total weight and 186 fish for liver and mesenteric fat weight.

The Bayesian credibility intervals of the predicted population averages (and their variances) for total weight, liver weight and mesenteric fat weight for each of the diets and for a size at release of $30 \mathrm{~cm}$ are shown in Table 4. These results demonstrate that the total weight was greatest for Diet G, closely followed by Diets A, B and F. The median total weight was $4.9 \mathrm{~g}$ less for Diet A than for Diet G. Furthermore, the experimental diets (C, D and E) yielded substantially lower weights than the other diets, with differences greater than $50 \mathrm{~g}$. Diet A had the highest liver weight (Table 4 ), although the values for diets A, B and G were all very similar. The results for liver weight were similar to those for total weight, with diets C, D and E yielding substantially lower liver weights than the other diets. The mesenteric fat weight was only weakly related to length for any diet $\left(\mathrm{R}^{2}<0.78\right)$, and the pattern of the relationship contrasted with the pattern found for total weight and for liver weight. For a size at release of 30 $\mathrm{cm}$, experimental Diets D and E yielded the highest 
A

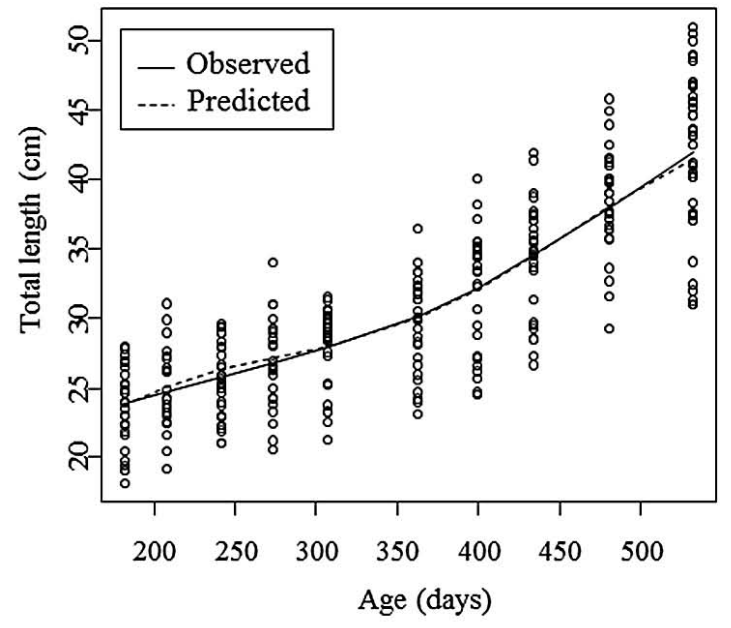

$\mathrm{B}$

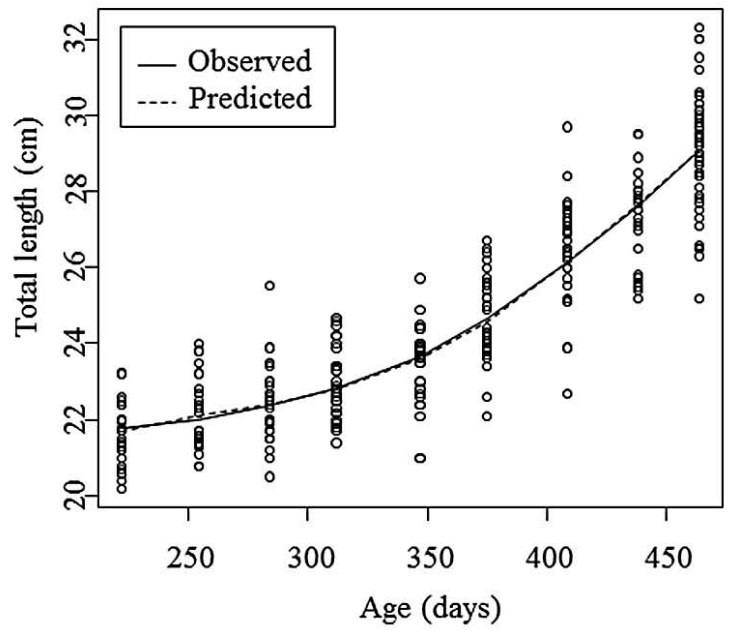

Fig. 1. - An example of the fit of the Somers' growth model to data from two randomly selected cages. A) Total length of the fish for the first replicate of Diet B in experiment 1. B) Total length of the fish for the third replicate of Diet E in experiment 2.

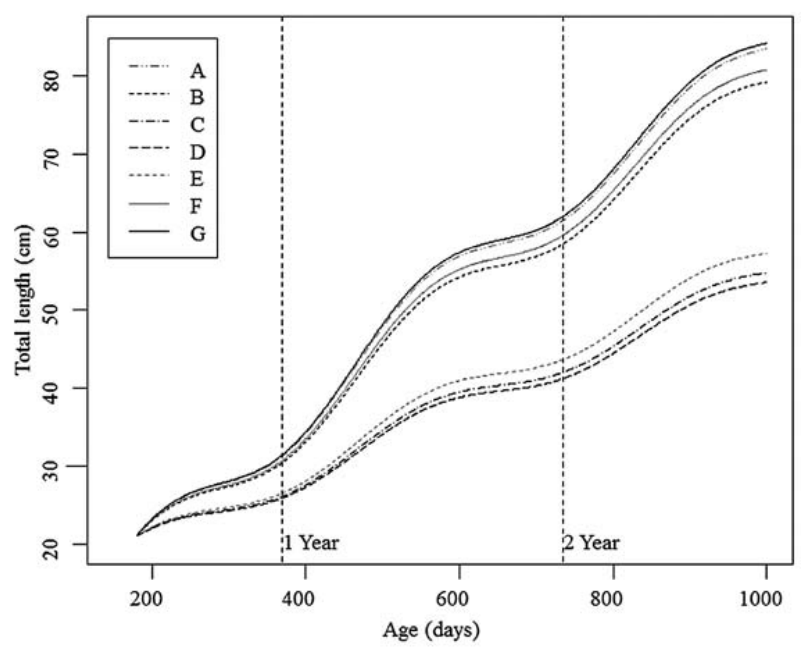

Fig. 2. - Estimated growth of A. regius juveniles for the seven tested diets during the grow-out phase.

median mesenteric fat weight (Table 4). Diet B also provided a considerable quantity of mesenteric fat. However, the other diets yielded median mesenteric fat weights of less than $1 \mathrm{~g}$.

Significant differences were observed in the ash, moisture, crude fat and crude protein composition of the fish on the seven diets (ash: $\mathrm{F}=18.8, \mathrm{P}<0.05$; moisture: $\mathrm{F}=20.5, \mathrm{P}<0.05$; crude fat: $\mathrm{F}=19.4, \mathrm{P}<0.05$; crude protein: $\mathrm{F}=11.9, \mathrm{P}<0.05)$. The crude fat content of the fish on Diets A, B, F and G was significantly higher than that of the fish on Diets C, D and E (Fig. 3A).
Table 3. - Posterior descriptors (median and 95\% credibility interval) of the relevant model parameters, where $t_{\mathrm{S}}$ is given in days and $\mathrm{K}$ in days ${ }^{-1}$. Variability at fish, cage and year levels is indicated by tolerance (1/variance). Note that variability of $\mathrm{K}_{\text {cage }}$ and $\mathrm{K}_{\mathrm{year}}$ is

\begin{tabular}{lccc}
\multicolumn{4}{c}{ small. } \\
\hline & $2.5 \%$ & Median & $97.5 \%$ \\
\hline $\mathrm{t}_{\mathrm{S}}$ & 104.3 & 107.5 & 110.9 \\
$\mathrm{C}$ & 0.68 & 0.71 & 0.74 \\
$\mathrm{~K}_{\text {diet }}$ Diet A & $3.3910^{-4}$ & $4.7710^{-4}$ & $6.1210^{-4}$ \\
$\mathrm{~K}_{\text {diet }}$ Diet B & $3.0910^{-4}$ & $4.4110^{-4}$ & $5.9510^{-4}$ \\
$\mathrm{~K}_{\text {diet }}$ Diet C & $0.6210^{-4}$ & $2.2610^{-4}$ & $4.1510^{-4}$ \\
$\mathrm{~K}_{\text {diet }}$ Diet D & $0.5610^{-4}$ & $2.2010^{-4}$ & $4.0810^{-4}$ \\
$\mathrm{~K}_{\text {diet }}$ Diet E & $0.8410^{-4}$ & $2.4810^{-4}$ & $4.3410^{-4}$ \\
$\mathrm{~K}_{\text {diet }}$ Diet F & $3.1110^{-4}$ & $4.5110^{-4}$ & $5.8410^{-4}$ \\
$\mathrm{~K}_{\text {diet }}$ Diet G & $3.3610^{-4}$ & $4.8610^{-4}$ & $6.1910^{-4}$ \\
Tolerance fish & 0.20 & 0.21 & 0.22 \\
Tolerance cage $\left(\mathrm{K}_{\text {cage }}\right)$ & $9.910^{8}$ & $9.910^{8}$ & $1.010^{9}$ \\
Tolerance year $\left(\mathrm{K}_{\text {year }}\right)$ & $1.410^{7}$ & $2.810^{8}$ & $6.010^{9}$ \\
\hline
\end{tabular}

Similar results were observed for the crude protein content (Fig. 3B), with average values in a much narrower range (17-18.5\%). The crude protein content of Diet $F$ was intermediate in value between the diets with the highest content (A, B and $\mathrm{G}$ ) and the diets with the lowest content (C, D and $\mathrm{E})$.

\section{Production costs}

The total costs and the percentage of feeding and personnel costs were obtained for each diet (Table 5). As the desired size at release increased, the relative proportion of feeding costs also increased. However, the proportion of the total associated with personnel costs was higher than that of feeding costs for all the

Table 4. - Summary of the weight-length analysis results for the total, liver and mesenteric fat weights of the different diets for a desired size at release of $30 \mathrm{~cm}$, with the median value and lower and upper $2.5 \%$ percentiles of the Bayesian credibility intervals for the estimated weights $(\mathrm{g})$.

\begin{tabular}{ccccccccc}
\hline Diets & $2.5 \%$ & $\begin{array}{c}\text { Total weight } \\
\text { Median }\end{array}$ & $97.5 \%$ & $2.5 \%$ & $\begin{array}{c}\text { Liver weight } \\
\text { Median }\end{array}$ & $97.5 \%$ & $\begin{array}{c}\text { Mesenteric fat weight } \\
\text { Median }\end{array}$ \\
\hline A & 289.54 & 326.64 & 368.80 & 5.39 & 7.65 & 10.93 & 0.19 & 0.80 \\
B & 285.78 & 323.44 & 365.61 & 5.30 & 7.46 & 10.54 & 0.29 & 1.19 \\
C & 237.03 & 267.78 & 302.21 & 2.61 & 3.69 & 5.28 & 0.17 & 0.73 \\
D & 241.07 & 272.33 & 307.30 & 3.14 & 4.45 & 6.30 & 0.41 & 1.69 \\
E & 237.42 & 267.83 & 302.69 & 2.90 & 4.10 & 5.82 & 0.36 \\
F & 284.81 & 321.69 & 363.83 & 4.77 & 6.72 & 9.50 & 0.08 & 1.56 \\
G & 293.11 & 331.58 & 375.49 & 5.21 & 7.44 & 10.57 & 0.16 & 0.34 \\
\hline
\end{tabular}


A

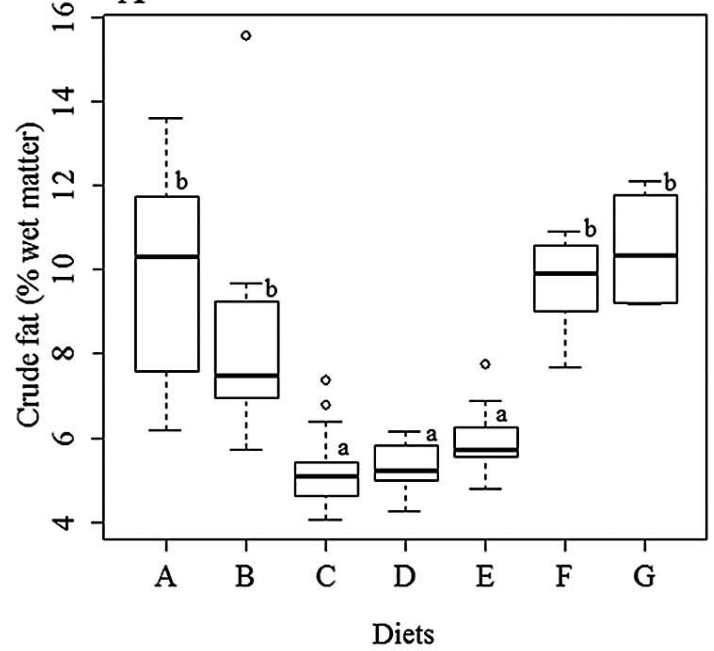

B

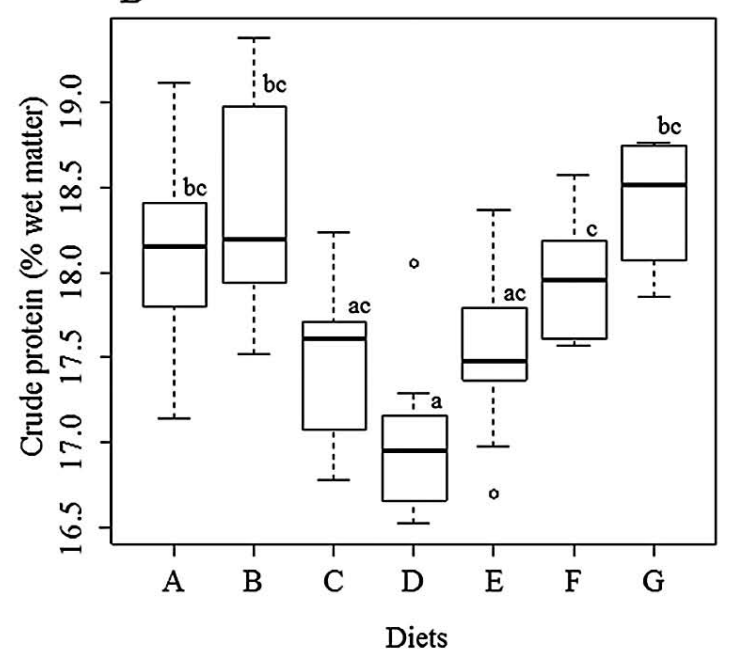

Fig. 3. - Boxplots of the A) crude fat content and B) crude protein content for fish reared on the tested diets. A line within the box marks the median values, and the boundary of the box indicates the $25 \%$ and $75 \%$ percentiles. The results of the pairwise comparisons, using a Tukey test, are represented by different letters.

Table 5. - The total $\left(\mathrm{CO}\right.$, in $€$ fish $\left.^{-1}\right)$, feeding (FCO, in \%) and personnel costs (PCO, in \%) for each diet relative to some possible size at release $(\mathrm{L}$, in $\mathrm{cm})$.

\begin{tabular}{|c|c|c|c|c|c|c|c|c|c|c|c|c|}
\hline \multirow{2}{*}{ Diets } & \multicolumn{3}{|c|}{$\mathrm{L}=25$} & \multicolumn{3}{|c|}{$\mathrm{L}=30$} & \multicolumn{3}{|c|}{$\mathrm{L}=35$} & \multicolumn{3}{|c|}{$\mathrm{L}=40$} \\
\hline & FCO & PCO & $\mathrm{CO}$ & $\mathrm{FCO}$ & PCO & $\mathrm{CO}$ & $\mathrm{FCO}$ & PCO & $\mathrm{CO}$ & $\mathrm{FCO}$ & PCO & $\mathrm{CO}$ \\
\hline A & 9.9 & 90.1 & 1.3 & 14.0 & 86.0 & 4.2 & 16.2 & 83.8 & 5.5 & 19.0 & 81.0 & 6.7 \\
\hline B & 10.1 & 89.9 & 1.5 & 14.3 & 85.7 & 4.4 & 16.4 & 83.6 & 5.7 & 19.5 & 80.5 & 7.0 \\
\hline $\mathrm{C}$ & 9.0 & 91.0 & 3.8 & 10.6 & 89.4 & 5.9 & 12.8 & 87.2 & 8.9 & 15.4 & 84.6 & 13.2 \\
\hline $\mathrm{D}$ & 9.5 & 90.5 & 3.9 & 11.2 & 88.8 & 6.0 & 13.7 & 86.3 & 9.9 & 16.3 & 83.7 & 13.6 \\
\hline $\mathrm{E}$ & 9.9 & 90.1 & 3.6 & 11.5 & 88.5 & 5.7 & 14.2 & 85.8 & 7.9 & 16.9 & 83.1 & 12.8 \\
\hline $\mathrm{F}$ & 9.5 & 90.5 & 1.5 & 13.4 & 86.6 & 4.4 & 15.4 & 84.6 & 5.6 & 18.3 & 81.7 & 6.8 \\
\hline $\mathrm{G}$ & 26.6 & 73.4 & 1.6 & 35.0 & 65.0 & 5.6 & 39.1 & 60.9 & 7.5 & 43.9 & 56.1 & 9.6 \\
\hline
\end{tabular}

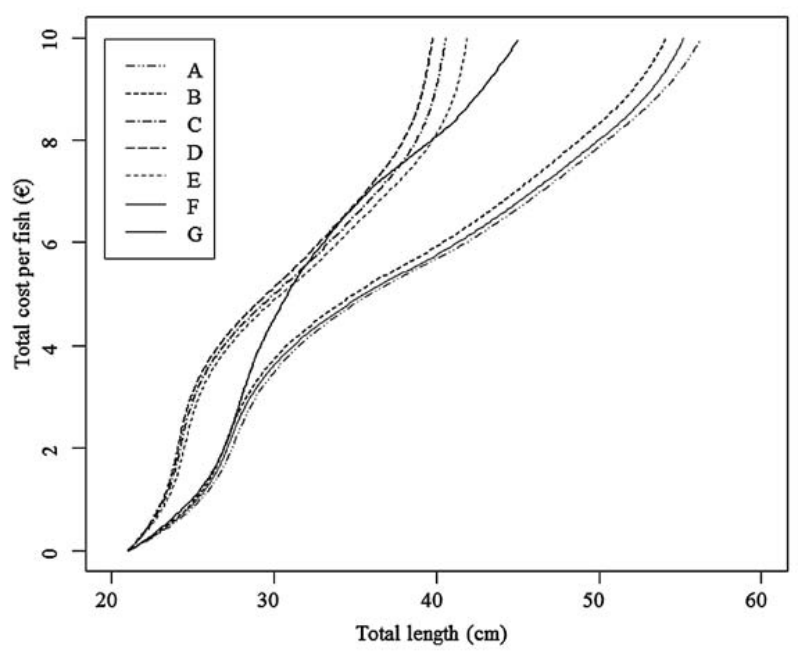

Fig. 4. - Size-dependent total cost (€) for a fish fed with each of the seven tested diets during the grow-out phase.

analysed lengths. Even in the case of diet G, for which the cost of raw materials was highest, the proportion of personnel costs was greater than the feeding cost, although the feeding and personnel costs were almost equal for a length of $40 \mathrm{~cm}$.

Diet A yielded the lowest production cost at any release length (Fig. 4). The experimental diets (C, D and E) had the highest total cost because of the poor growth observed. This implies that the fish had to
Table 6. - Number of fish that can be produced for a target size of $30 \mathrm{~cm}$ with a given budget of $€ 1000$. Daily mortality was assumed to be $0.012 \%$.

\begin{tabular}{cc}
\hline Diets & Number of fish \\
\hline A & 2328 \\
B & 2234 \\
C & 1665 \\
D & 1626 \\
E & 1724 \\
F & 2267 \\
G & 1768 \\
\hline
\end{tabular}

be fed for a longer time to reach the desired length than the fish fed with the other diets, thus leading to greater personnel costs. Although the costs of Diet $G$ and Diet A were similar at the beginning of the growout phase, the total cost for producing fish larger than $25 \mathrm{~cm}$ with Diet $\mathrm{G}$ increased substantially over time. Therefore, despite the better growth furnished by Diet $\mathrm{G}$, this diet was not advantageous in terms of the total production costs.

The estimated number of fish for a given size (30 $\mathrm{cm})$ and with a given budget $(1000 €)$ is compared at Table 6. Diet A produced the largest number of fish.

\section{DISCUSSION}

The success of a restocking programme depends on complex tradeoffs, but in practice it could be considered a two-fold process. First, the post-release survival rate of hatchery-reared specimens is primarily depend- 
ent on the size/age and the quality of specimens at the time of release (Tsukamoto et al. 1999, Leber et al. 2005); larger fish tend to be more resilient. Second, success may depend on the number of fish released. However, both processes are limited by economic factors. The economic factors of restocking programmes have rarely been studied (Kellison and Eggleston 2004, Leber et al. 2005, Patrick et al. 2006), but play important roles in the recovery of several species.

While the size-dependent mortality rate of restocked meagre in the wild has been analysed elsewhere (Gil et al. 2015), here we focused on the methods for maximizing the number of fish to be released.

\section{Growth}

Growth of meagre is high during the grow-out phase and feed conversion rates (i.e. the proportion of food that is converted into biomass) are good (Duncan et al. 2013). Recently, meagre growth has been widely studied in different culture systems (Pastor et al. 2002, El-Shebly et al. 2007, Chatzifotis et al. 2010, Vargas-Chacoff et al. 2014) and with different diet compositions (Piccolo et al. 2008, Estévez et al. 2011, Chatzifotis et al. 2012, Velazco-Vargas et al. 2014) due to the increasing interest in meagre for diversification of aquaculture.

To compare the growth rate of juveniles that were fed with different diets was challenging in this study because fish showed a clear shift in growth rate following the winter (Fig. 1). As in most marine organisms (Pauly 1990, Alcoverro et al. 1995, Coma et al. 2000), the growth of A. regius appears to be influenced by seasonal changes. The growth rate clearly decreases at temperatures less than $16^{\circ} \mathrm{C}$ (Quéméner 2002, El-Shebly et al. 2007). For this reason, the conventional von Bertalanffy growth model did not adequately fit the growth pattern of the juvenile meagre on the diets tested in this study. The observed growth pattern was better described by introducing a seasonal oscillation rather than using the conventional formulation (Somers 1988, GarcíaBerthou et al. 2012, Gil et al. 2014b). This method yielded season-independent growth rates that were fully comparable among diets.

The diet experiments conducted with juvenile $A$. regius revealed that Diet $\mathrm{G}$ provided the best growth, because semi-moist diets appear to have better palatability than dry pellets. The second-best growth rate was obtained with Diet A (dry commercial pellets), but this diet minimized the cost of growing fish for any desired size at release (see below). The experimental diets $(\mathrm{C}$, $\mathrm{D}$ and E) clearly underperformed when compared with the others. This result supports the need for completing pilot studies for comparing different rearing protocols.

\section{Fish quality}

The expected fitness of fish released into a natural environment is a result of both fish quality and size (Tsukamoto et al. 1999). There is a long history of research on hatchery technologies aiming to produce high-quality juveniles not only for aquaculture but also for stock enhancement (Fushimi 2001, Shields 2001). Studies on red sea bream, Pagrus major have shown that the quality of hatchery-reared juveniles depends primarily on the nutritional quality of the diet (Nakano 1996, Le Vay et al. 2007). Similarly, the current study showed that the biological condition of the fish (estimated from the relationships between length and total weight, liver weight and mesenteric fat weight) and the biochemical composition of the entire fish body were influenced by the diets used to feed juvenile meagre.

The biochemical composition of the fish body (specifically, crude fat and protein) was similar and optimal for diets A, B, F and G but deficient for diets $\mathrm{C}, \mathrm{D}$ and $\mathrm{E}$. The proximate composition of cultured fish is affected by endogenous and exogenous factors. The levels of protein and ash are primarily related to fish size (endogenous factors), whereas fat content depends on exogenous factors, such as diet (Shearer 1994). Although exceptions occur, muscle with relatively low lipid content is common in many demersal species. These species are more sedentary than pelagic carnivores, which typically show burst swimming behaviour and thus sustain higher lipid levels in muscle tissue to fuel this response (Sheridan 1988).

Weight-length relationships were used for comparing body condition based on the assumption that heavier fish of a given length are in better condition than thinner fish (Froese 2006). Poor conditions may lower the chances of survival because fish are more susceptible to predation and to a variety of environmental stressors (Lloret et al. 2002). According to these criteria, fish on Diet $\mathrm{G}$ exhibited the best condition, followed by those on Diet A. Note, however, that diets A, B, F and G all yielded a very similar total weight for a size at release of $30 \mathrm{~cm}$. These total weights differed by only a few grams (Table 4). Additionally, note that the within-diet differences were large in comparison with the amongdiet differences (Table 4).

In fish, liver is considered a major fat and glycogen storage organ, and can provide an additional way to estimate nutritional state (Adams and Greeley 2000). Accordingly, correlations involving liver weight and fish length are calculated to estimate condition in fish (Benejam et al. 2010). In the current study, the measurements of fish condition based on liver weight were highest and almost equal for diets $\mathrm{A}, \mathrm{B}, \mathrm{F}$ and $\mathrm{G}$, indicating a higher accumulation of reserves. Chatzifotis et al. (2006) have suggested that the liver of the sciaenid brown meagre, Sciaena umbra, may serve as a storage organ for energy because of its relatively high lipid content $(39-43 \%)$. Furthermore, the low lipid content of muscle $(1-2.5 \%)$ observed in certain species of sciaenids (Poli et al. 2003, Hernández et al. 2009, Grigorakis et al. 2011) indicates the minor role of muscle as an energy storage tissue (Chatzifotis et al. 2006).

The experimental diets (C, D and E) clearly resulted in poorer growth, total weight and liver weight-length relationships. However, the mesenteric fat weightlength relationship yielded greater values than the other diets, indicating a substantial accumulation of mesenteric fat during the experiment. Piccolo et al. 
(2008) evaluated the effect of two diets with different protein/fat ratios $(\mathrm{P} / \mathrm{F})$ and found that, although the biometric traits analysed were not affected by the diet, the amount of mesenteric fat was significantly higher for diets with a lower protein/fat ratio. Too much dietary lipid may result in excessive fat deposition in the visceral cavity and tissues (Lanari et al. 1999). In fish, an appropriate energy-to-protein ratio in the diet contributes to the effective utilization of dietary proteins through the protein sparing effect (Watanabe 1982). Therefore, fish are able to utilize dietary lipids up to a certain level beyond which growth may be retarded because high energy intake depresses appetite before sufficient protein has been consumed to support growth (Ellis and Reigh 1991). However, meagre is a carnivorous species, feeding on Mysidacea, Decapoda and Teleostei in the wild (Cabral and Ohmert 2001, Gil et al. 2014a) (Chatzifotis et al. 2012), and does not appear to require high dietary lipid levels. At lipid levels greater than 17\%, Chatzifotis et al. (2010) did not observe a sparing effect on protein. Therefore, the mesenteric fat weight-length relationship should not be viewed as an indicator of good condition.

In summary, fish condition and biochemical composition suggest that all the diets except the experimental ones (i.e. C, D and E) produce fish of similar quality and are fully suited for use in a restocking programme.

\section{Cost}

Economic effectiveness is one of the most frequently criticized aspects of restocking programmes, although most restocking programmes have yet to be fully assessed because this aspect has received little or no attention (Hilborn 1998). However, economic viability has been demonstrated in certain cases: e.g. release programmes for Pacific salmon Oncorhynchus sp. (Isaksson 1988), Japanese flounder Paralichthys olivaceus and red sea bream P. major in Japan (Kitada 1999, Okouchi et al. 2004, Kitada and Kishino 2006).

In our case, the costs of the grow-out phase showed marked among-diet differences. The high cost of the semi-moist diet and its required cold storage limit the use of Diet G (Kubitza and Lovshin 1997, Kim and Shin 2006). Diet A was the best option for minimizing production costs for any size at release because this diet has both a reasonable price (unlike Diet G) and good growth performance, allowing fish to spend less time in the grow-out phase before attaining the desired size. This last point is decisive because time savings imply reduced personnel costs, which represent the largest component of the total cost (see Table 5).

Despite the favourable results obtained with Diet $\mathrm{A}$, the absolute cost of the grow-out phase was higher than the costs obtained in other studies of the entire production process (Svåsand et al. 2000, Leber et al. 2005, Patrick et al. 2006). However, it is important to note that LIMIA facilities are designed for research purposes. Continuous improvement in hatchery technology minimizes production costs (Sproul and Tominaga 1992, Ungson et al. 1993). so it is expected that productivity will be largely improved at facilities spe- cialized in producing fish for restocking. Nevertheless, production capability is somewhat limited and producing large numbers of large specimens is unreliable given, for example, the spatial limitations of hatcheries (Kellison and Eggleston 2004). Ultimately, the annual budget imposes a limit to the number and size of the fish that can be produced.

In conclusion, Diet A was the best option for the production of juvenile meagre for a restocking programme. This diet was capable of producing quality juveniles while minimizing production costs for any possible size at release and maximizing the number of juveniles that could be produced on a fixed budget. However, other factors that need further study include the magnitude of the release (i.e. the critical number of released fish), the survival of released fish (Gil et al. 2015) and the economic value of the fish (fisher profits). All of these factors must be considered for a suitable assessment of the cost-effectiveness of a restocking programme. Adapting and improving the programme in light of the results of pilot studies and incorporating the opinions of different stakeholders into decision making may successfully facilitate the design of restocking programmes that are socially acceptable, economically viable and environmentally sustainable (Bartley and Bell 2008).

\section{ACKNOWLEDGEMENTS}

This work is a result of the "Unidad Asociada I+D+I LIMIA-IMEDEA". The authors thank the staff of LIMIA, E. Massutí and G. Palmer for assisting with fish reproduction and larval rearing and for help with the management of the diet experiments. Additionally, we would like to express our thanks to the technician at IMIDA, C. Martínez, for the biochemical analyses. This work was financially supported by the MAPAJACUMAR project "National Plan for Breeding of Meagre, Argyrosomus regius" and INIA projects RTA2007 00033-C02-01 and RTA-2011 00056-C02-00 and RECUMARE.

\section{REFERENCES}

Adams S.M., Greeley M.S. 2000. Ecotoxicological indicators of water quality: using multi-response indicators to assess the health of aquatic ecosystems. Water, Air, Soil Pollut. 123: 103-115. http://dx.doi.org/10.1023/A:1005217622959

Alcoverro T., Duarte C.M., Romero J. 1995. Annual growth dynamics of Posidonia oceanica: contribution of large-scale versus local factors to seasonality. Mar. Ecol. Prog. Ser. 120: 203-210. http://dx.doi.org/10.3354/meps 120203

AOAC. 1997. Official Methods of Analysis. Association of Official Analytical Chemists, USA.

Bartley D.M., Bell J.D. 2008. Restocking, stock enhancement, and sea ranching: Arenas of progress. Rev. Fish. Sci. 16: 357-365. http://dx.doi.org/10.1080/10641260701678058

Bell J.D., Bartley D.M., Lorenzen K., et al. 2006. Restocking and stock enhancement of coastal fisheries: Potential, problems and progress. Fish. Res. 80: 1-8. http://dx.doi.org/10.1016/j.fishres.2006.03.008

Benejam L., Benito J., García-Berthou E. 2010. Decreases in condition and fecundity of freshwater fishes in a highly polluted reservoir. Water, Air, Soil Pollut. 210: 231-242. http://dx.doi.org/10.1007/s11270-009-0245-z

Blankenship H.L., Leber K.M. 1995. A responsible approach to marine stock enhancement. Am. Fish. Soc. Symp. 15: 167-175. 
Born A.F., Immink A.J., Bartley D.M. 2004. Marine and coastal stocking: global status and information needs. In: Bartley D.M., Leber K.M. (eds), Marine Ranching. FAO Fisheries Technical Paper, pp. 1-12.

Brown C. Day R.L. 2002. The future of stock enhancements: lessons for hatchery practice from conservation biology. Fish Fish. 3: 79-94.

http://dx.doi.org/10.1046/j.1467-2979.2002.00077 x

Cabral H.N., Ohmert B. 2001. Diet of juvenile meagre, Argyrosomus regius, within the Tagus estuary. Cah. Biol. Mar. 42: 289-293.

Coma R., Ribes M., Gili J.-M., et al. 2000. Seasonality in coasta benthic ecosystems. Trends Ecol. Evol. 15: 448-453. http://dx.doi.org/10.1016/S0169-5347(00)01970-4

Cowx I.G. 1994. Stocking strategies. Fish. Manage. Ecol. 1: 15-30. http://dx.doi.org/10.1111/j.1365-2400.1970.tb00003.x

Chao N.L. 1986. Sciaenidae. In: Whitehead P.J.P., Bauchot M.-L., Hureau J.C., et al. (eds), Poissons de l'Atlantique du Nord-est et de la Méditerranée. Unesco, pp. 865-874.

Chatzifotis S., Villamor Martin-Prat A., Limberis N. et al. 2006. First data on growth of cultured brown meagre Sciaena umbra using diets with different protein and fat contents. Fish. Sci. 72: $83-88$ http://dx.doi.org/10.1111/j.1444-2906.2006.01120.x

Chatzifotis S., Panagiotidou M., Papaioannou N., et al. 2010. Effect of dietary lipid levels on growth, feed utilization, body composition and serum metabolites of meagre (Argyrosomus regius) juveniles. Aquaculture 307: 65-70 http://dx.doi.org/10.1016/j.aquaculture.2010.07.002

Chatzifotis S., Panagiotidou M., Divanach P. 2012. Effect of protein and lipid dietary levels on the growth of juvenile meagre (Argyrosomus regius). Aquacult. Int. 20: 91-98. http://dx.doi.org/10.1007/s10499-011-9443-y

Duncan N.J., Estévez A., Fernández-Palacios H., et al. 2013. Aquaculture production of meagre (Argyrosomus regius): hatchery techniques, ongrowing and market. In: Allan G., Burnell G. (eds), Advances in Aquaculture Hatchery Technology. Woodhead Publishing Limited, pp. 519-541. http://dx.doi.org/10.1533/9780857097460.3.519

El-Shebly A.A., El-Kady M.A.H., Hussin A.B., et al. 2007. Preliminary observations on the pond culture of meagre, Argyrosomus regius (Asso, 1801) (Sciaenidae) in Egypt. J. Fish. Aquat. Sci. 2: $345-352$ http://dx.doi.org/10.3923/jfas.2007.345.352

Ellis S.C., Reigh R.C. 1991. Effects of dietary lipid and carbohydrate levels on growth and body composition of juvenile red drum, Sciaenops ocellatus. Aquaculture 97: 383-394. http://dx.doi.org/10.1016/0044-8486(91)90330-A

Estévez A., Treviño L., Kotzamanis Y., et al. 2011. Effects of different levels of plant proteins on the ongrowing of meagre (Argyrosomus regius) juveniles at low temperatures. Aquacult. Nutr. 17: 572-582. http://dx.doi.org/10.1111/j.1365-2095.2010.00798.x

Froese R. 2006. Cube law, condition factor and weight-length relationships: history, meta-analysis and recommendations. J. Appl. Ichthyol. 22: 241-253. http://dx.doi.org/10.1111/j.1439-0426.2006.00805.x

Fushimi H. 2001. Production of juvenile marine finfish for stock enhancement in Japan. Aquaculture 200: 33-53. http://dx.doi.org/10.1016/S0044-8486(01)00693-7

García-Berthou E., Carmona-Catot G., Merciai R., et al. 2012. A technical note on seasonal growth models. Rev. Fish Biol. Fish. 22: 635-640. http://dx.doi.org/10.1007/s11160-012-9262-x

Gil M.M., Palmer M., Grau A., et al. 2014a. Adapting to the wild: the case of aquaculture-produced and released meagres Argyrosomus regius. J. Fish Biol. 84: 10-30. http://dx.doi.org/10.1111/jfb.12241

Gil M.M., Palmer M., Grau A., et al. 2014b. First evidence on the growth of hatchery-reared juvenile meagre Argyrosomus regius released in the Balearic Islands coastal region. Aquaculture 434: 78-87.

http://dx.doi.org/10.1016/j.aquaculture.2014.07.032

Gil M.M., Palmer M., Grau A., et al. 2015. Many vulnerable or a few resilient specimens? Finding the optimal for reintroduction/ restocking programs. PLoS One 10(9): e0138501. http://dx.doi.org/10.1371/journal.pone.0138501.

González-Quirós R., del Árbol J., García-Pacheco M.M., et al. 2011. Life-history of the meagre Argyrosomus regius in the Gulf of Cádiz (SW Iberian Peninsula). Fish. Res. 109: 140-149. http://dx.doi.org/10.1016/j.fishres.2011.01.031
Grigorakis K., Fountoulaki E., Vasilaki A., et al. 2011. Lipid quality and filleting yield of reared meagre (Argyrosomus regius). Int. J. Food Sci. Technol. 46: 711-716. http://dx.doi.org/10.1111/j.1365-2621.2010.02537.x

Hernández M.D., López M.B., Álvarez A., et al. 2009. Sensory, physical, chemical and microbiological changes in aquacultured meagre (Argyrosomus regius) fillets during ice storage. Food Chem. 114: 237-245. http://dx.doi.org/10.1016/j.foodchem.2008.09.045

Hilborn R. 1998. The economic performance of marine stock enhancement projects. Bull. Mar. Sci. 62: 661-674.

Iglesias J., Ojea G., Otero J.J., et al. 2003. Comparison of mortality of wild and released reared 0-group turbot, Scophthalmus maximus, on an exposed beach (Ría de Vigo, NW Spain) and a study of the population dynamics and ecology of the natural population. Fish. Manage. Ecol. 10: 51-59. http://dx.doi.org/10.1046/j.1365-2400.2003.00318.x

Ireland S.C., Beamesderfer R.C.P., Paragamian V.L., et al. 2002. Success of hatchery-reared juvenile white sturgeon (Acipenser transmontanus) following release in the Kootenai River, Idaho, USA. J. Appl. Ichthyol. 18: 642-650. http://dx.doi.org/10.1046/j.1439-0426.2002.00364.x

Isaksson A. 1988. Salmon ranching: a world review. Aquaculture 75: $1-33$. http://dx.doi.org/10.1016/0044-8486(88)90018-X

Kam L.E., Leung P., Ostrowski A.C., et al. 2002. Size economies of a Pacific threadfin Polydactylus sexfilis hatchery in Hawaii. J. World Aquac. Soc. 33: 410-424. http://dx.doi.org/10.1111/j.1749-7345.2002.tb00020.x

Kellison G.T., Eggleston D.B. 2004. Coupling ecology and economy: modeling optimal release scenarios for summer flounder (Paralichthys dentatus) stock enhancement. Fish. Bull. 102: 78-93.

Kim J.D., Shin S.H. 2006. Growth, feed utilization and nutrient retention of juvenile olive flounder (Paralichthys olivaceus) fed moist, semi-moist and extruded diets. Asian Australas. J. Anim. Sci. 19: 720-726. http://dx.doi.org/10.5713/ajas.2006.720

Kitada S. 1999. Contribution of hatchery enhancement and comprehensive fishery resource management: from Japanese experience. Marine Ranching: Global Perspectives with Emphasis on the Japanese Experience. FAO Fisheries Circular, pp. 98-130.

Kitada S., Kishino H. 2006. Lessons learned from Japanese marine finfish stock enhancement programmes. Fish. Res. 80: 101-112. http://dx.doi.org/10.1016/j.fishres.2006.03.019

Kristiansen T.S., Jørstad K.E., Otterå H., et al. 1997. Estimates of larval survival of cod by releases of genetically marked yolksac larvae. J. Fish Biol. 51: 264-283. http://dx.doi.org/10.1111/j.1095-8649.1997.tb06103.x

Kubitza F., Lovshin L.L. 1997. The use of freeze-dried krill to feed train largemouth bass (Micropterus salmoides): feeds and training strategies. Aquaculture 148: 299-312. http://dx.doi.org/10.1016/S0044-8486(96)01426-3

Lanari D., Poli B.M., Ballestrazzi R., et al. 1999. The effects of dietary fat and NFE levels on growing European sea bass (Dicentrarchus labrax L.). Growth rate, body and fillet composition, carcass traits and nutrient retention efficiency. Aquaculture 179: $351-364$ http://dx.doi.org/10.1016/S0044-8486(99)00170-2

Lazo J.P., Holt J.G., Fauvel C., et al. 2010. Drum-fish or Croakers (Family: Sciaenidae). In: Le Francois N., Jobling M., Carter C., et al. (eds), Finfish Aquaculture Diversification. CABI, pp. $397-431$. http://dx.doi.org/10.1079/9781845934941.0397

Le Vay L., Carvalho G.R., Quinitio E.T., et al. 2007. Quality of hatchery-reared juveniles for marine fisheries stock enhancement. Aquaculture 268: 169-180. http://dx.doi.org/10.1016/j.aquaculture.2007.04.041

Leber K.M. 1995. Significance of fish size-at-release on enhancement of striped mullet fisheries in Hawaii. J. World Aquac. Soc. 26: $143-153$. http://dx.doi.org/10.1111/j.1749-7345.1995.tb00237.x

Leber K.M., Cantrell R.N., Leung P. 2005. Optimizing cost-effectiveness of size at release in stock enhancement programs. North Am. J. Fish. Manage. 25: 1596-1608. http://dx.doi.org/10.1577/M04-093.1

Leung P.S., Lee C.S., Rowland L.W. 1993. Production cost for a finfish hatchery: the case of striped mullet (Mugil cephalus). In: Lee C.S., Su M.S., Liao I.C. (eds), Finfish Hatchery in Asia: Proceedings of Finfish Hatchery in Asia '91. Tungkang Marine 
Laboratory, pp. 239-244.

Lloret J., Gil de Sola L., Souplet A., et al. 2002. Effects of largescale habitat variability on condition of demersal exploited fish in the north-western Mediterranean. ICES J. Mar. Sci. 59: 1215-1227.

http://dx.doi.org/10.1006/jmsc.2002.1294

Marshall C.T., Needle C.L., Yaragina N.A., et al. 2004. Deriving condition indices from standard fisheries databases and evaluating their sensitivity to variation in stored energy reserves. Can. J. Fish. Aquat. Sci. 61: 1900-1917. http://dx.doi.org/10.1139/f04-128

Mayol J., Grau A.M., Riera F., et al. 2000. Llista Vermella dels Peixos de les Balears. Conselleria de Medi Ambient-Conselleria d'Agricultura i Pesca, Spain, 126 pp.

Miglavs I., Jobling M. 1989. The effects of feeding regime on proximate body composition and patterns of energy deposition in juvenile Arctic charr, Salvelinus alpinus. J. Fish Biol. 35: 1-11. http://dx.doi.org/10.1111/j.1095-8649.1989.tb03387.x

Millamena O.M. 2002. Replacement of fish meal by animal byproduct meals in a practical diet for grow-out culture of grouper Epinephelus coioides. Aquaculture 204: 75-84. http://dx.doi.org/10.1016/S0044-8486(01)00629-9

Monfort M.C. 2010. Present Market Situation and Prospects of Meagre (Argyrosomus regius), as an Emerging Species in Mediterranean Aquaculture. FAO, Italy.

Munro J.L., Bell J.D. 1997. Enhancement of marine fisheries resources. Rev. Fish. Sci. 5: 185-222. http://dx.doi.org/10.1080/10641269709388597

Nakano H. 1996. Comprehensive methodology of evaluation on the finfish larval health. JASFA Bull. 68: 48-54

Okouchi H., Kitada S., Iwamoto A., et al. 2004. Flounder stock enhancement in Miyako Bay, Japan. In: Bartley D., Leber K.M. (eds), Marine ranching. FAO Fisheries Technical Paper, pp. 171-202.

Pastor E., Grau A. 2013. Cultivo de Esciénidos. I: La corvina. In: Oesa, IEO (eds), Diversificación de especies en la piscicultura marina española. Publicaciones científicas de la Fundación Observatorio Español de Acuicultura, pp. 121-157.

Pastor E., Grau A., Massutí-Pascual E., et al. 2002. Preliminary results on growth of meagre, Argyrosomus regius (Asso 1801) in sea cages and indoor tanks. Eur. Aquac. Soc. Spec. Publ. 32: 422-423.

Patrick W.S., Bin O., Schwabe K.A., et al. 2006. Hatchery programs, stock enhancement, and cost effectiveness: A case study of the Albemarle Sound/Roanoke River stocking program 1981-1996. Mar. Policy 30: 299-307. http://dx.doi.org/10.1016/j.marpol.2005.02.003

Pauly D. 1990. Length-converted catch curves and the seasonal growth of fishes. Fishbyte 8: 33-38.

Pepper V.A., Nicholls T., Oliver N.P. 1992. An evaluation of the quality of fall-fingerling Atlantic salmon (Salmo salar L.) released to natural lacustrine nursery areas in Newfoundland, Canada. Hydrobiologia 243-244: 249-259. http://dx.doi.org/10.1007/BF00007040

Piccolo G., Bovera F., De Riu N., et al. 2008. Effect of two different protein/fat ratios of the diet on meagre (Argyrosomus regius) traits. Ital. J. Anim. Sci. 7: 363-371.

Poli B.M., Parisi G., Zampacavallo G., et al. 2003. Preliminary results on quality and quality changes in reared meagre (Argyrosomus regius): body and fillet traits and freshness changes in refrigerated commercial-size fish. Aquacult. Int. 11: 301-311. http://dx.doi.org/10.1023/A:1024840804303

Quéméner L. 2002. Le maigre commun (Argyrosomus regius). Biologie, peche, marche et potentiel aquacole. Editions IFREMER, France.

Quéro J.C., Vayne J.J. 1987. The meagre, Argyrosomus regius (Asso, 1801) (Pisces, Perciformes, Sciaenidae) from the Bay of Biscay and from more septentrional waters. Rev. Trav. Inst. Pêches Marit. 49: 35-66.

Roo J., Hernández-Cruz C.M., Borrero C., et al. 2010. Effect of larval density and feeding sequence on meagre (Argyrosomus regius; Asso, 1801) larval rearing. Aquaculture 302: 82-88. http://dx.doi.org/10.1016/j.aquaculture.2010.02.015

Sadovy Y., Cheung W.L. 2003. Near extinction of a highly fecund fish: the one that nearly got away. Fish Fish. 4: 86-99. http://dx.doi.org/10.1046/j.1467-2979.2003.00104.x

Schnute J., Fournier D. 1980. A new approach to length-frequency analysis: growth structure. Can. J. Fish. Aquat. Sci. 37: 1337-1351. http://dx.doi.org/10.1139/f80-172

Shearer K.D. 1994. Factors affecting the proximate composition of cultured fishes with emphasis on salmonids. Aquaculture 119: 63-88. http://dx.doi.org/10.1016/0044-8486(94)90444-8

Sheridan M.A. 1988. Lipid dynamics in fish: aspects of absorption, transportation, deposition and mobilization. Comp. Biochem. Physiol. B: Biochem. Mol. Biol. 90: 679-690 http://dx.doi.org/10.1016/0305-0491(88)90322-7

Shields R.J. 2001. Larviculture of marine finfish in Europe. Aquaculture 200: 55-88. http://dx.doi.org/10.1016/S0044-8486(01)00694-9

Somers I.F. 1988. On a seasonally oscillating growth function. Fishbyte 6: 8-11.

Sparrevohn C.R., Støttrup J.G. 2007. Post-release survival and feeding in reared turbot. J. Sea Res. 57: 151-161. http://dx.doi.org/10.1016/j.seares.2006.08.010

Sproul J.T., Tominaga O. 1992. An economic review of the Japanese flounder stock enhancement project in Ishikari Bay, Hokkaido. Bull. Mar. Sci. 50: 75-88.

Svåsand T., Kristiansen T.S. 1990. Enhancement studies of coastal cod in western Norway. Part IV. Mortality of reared cod after release. J. Cons. int. Explor. Mer 47: 30-39. http://dx.doi.org/10.1093/icesjms/47.1.30

Svåsand T., Kristiansen T.S., Pedersen T., et al. 2000. The enhancement of cod stocks. Fish Fish. 1: 173-205. http://dx.doi.org/10.1046/j.1467-2979.2000.00017.x

Tominaga O., Watanabe Y. 1998. Geographical dispersal and opti mum release size of hatchery-reared Japanese flounder Paralichthys olivaceus released in Ishikari Bay, Hokkaido, Japan. J. Sea Res. 40: 73-81. http://dx.doi.org/10.1016/S1385-1101(98)00011-2

Tsukamoto K., Kuwada H., Hirokawa J., et al. 1989. Size-dependent mortality of red sea bream, Pagrus major, juveniles released with fluorescent otolith-tags in News Bay, Japan. J. Fish Biol. 35: 59-69. http://dx.doi.org/10.1111/j.1095-8649.1989.tb03046.x

Tsukamoto K., Kuwada H., Uchida K., et al. 1999. Fish quality and stocking effectiveness: behavioural approach. In: Howell B.R., Moksness E., Svåsand T. (eds), Stock Enhancement and Sea Ranching. Fishing News Books, pp. 203-218.

Ungson J.R., Matsuda Y., Hirata H., et al. 1993. An economic assessment of the production and release of marine fish fingerlings for sea ranching. Aquaculture 118: 169-181. http://dx.doi.org/10.1016/0044-8486(93)90454-7

Vargas-Chacoff L., Ruiz-Jarabo I., Páscoa I., et al. 2014. Yearly growth and metabolic changes in earthen pond-cultured meagre Argyrosomus regius. Sci. Mar. 78: 193-202. http://dx.doi.org/10.3989/scimar.03965.06B

Velazco-Vargas J., Tomás-Vidal A., Hamdan M., et al. 2014. Influence of digestible protein levels on growth and feed utilization of juvenile meagre Argyrosomus regius. Aquacult. Nutr. 20: $520-531$ http://dx.doi.org/10.1111/anu.12105

Watanabe T. 1982. Lipid nutrition in fish. Comp. Biochem. Physiol. B: Biochem. Mol. Biol. 73: 3-15. http://dx.doi.org/10.1016/0305-0491(82)90196-1

Wilby A., Mitchell C.E., Blumenthal D., et al. 2009. Biodiversity, food provision and human health. In: Sala O.E., Meyerson L.A. (eds), Biodiversity change and human health: from ecosystem services to spread of disease. Island Press, pp. 13-40. 